\title{
Effects of Acetaminophen and Vitamin Supplement on Feed intake, Body Weight, and Acute Pain Responses of Pullets Subjected to Beak-trimming
}

\author{
Nkiruka O. Okoroafor ${ }^{1}$, Nnamdi H. Okereke ${ }^{2 *}$, and Ijeoma R. Udegbunam ${ }^{3}$ \\ ${ }^{I}$ Department of Veterinary Medicine, Faculty of Veterinary Medicine, University of Nigeria, Nsukka, Nigeria \\ ${ }^{2}$ Department of Veterinary Surgery, Faculty of Veterinary Medicine, University of Nigeria, Nsukka, Nigeria \\ ${ }^{3}$ Department of Veterinary Surgery, Faculty of Veterinary Medicine, University of Nigeria, Nsukka, Nigeria \\ *Corresponding author’s Email: nnamdi.okereke@unn.edu.ng; ORCID: 0000-0002-4339-6899
}

Received: 26 Dec. 2020 Accepted: 07 Feb. 2021

\begin{abstract}
The first experiment aimed to compare the effects of manual and electric beak-trimming on feed intake, body weight, and some biochemical parameters of eight-week-old pullets. A total of 20 pullets aged 3 weeks were assigned to two treatment groups; those in group A were manually debeaked while the samples in group B were electro debeaked. The findings indicated that 2 hours post-beak-trimming (PBT), the packed-cell volume of group A was significantly higher than that of group B. Plasma cortisol level of group A was significantly higher than that of group B at 2 and 6 hours PBT while total plasma protein level of group A was significantly lower than that of the group at 2 and 72 hours PBT. Furthermore, feed intake and body weight markedly decreased in the pullets debeaked with both methods until 72 hours PBT. The chickens' beak trimmed with both methods experienced intense pain of varying degrees lasting up to 72 hours. In the second experiment, 40 eight-week-old pullets were assigned to four groups; group A was the control, group B was treated with a vitamin supplement, group C was treated with acetaminophen, and group D was treated with vitamin supplement plus acetaminophen. After 24 hours, chickens were beak-trimmed using a manual cutter. The results revealed that 2 hours PBT, plasma cortisol level in groups B, C, and D were significantly lower than that of group A. Blood glucose was lowest in groups A and D at 6 and 24 hours PBT, respectively. It is concluded that the pre-treatment with vitamins and NSAIDs could reduce stress and pain in debeaked chickens.
\end{abstract}

Keywords: Anti-stress, Debeaking, Pain, Pullet

\section{INTRODUCTION}

Beak-trimming, formerly known as debeaking, is a routine husbandry procedure performed in many poultry species, such as laying hens, turkeys, ducks, and quails (Gentle et al., 1995; Gustafson et al., 2007; Fournier et al., 2015). It is the act of amputation or cauterization of approximately one-quarter to one-third of the upper beak or both upper and lower beak of a bird (Gentle et al., 1995; Van Liere, 1995) to prevent aggressive behaviors, feather pecking, and cannibalization (Dennis et al., 2009). There are several methods for debeaking, including mechanical beak-trimming using simple blades or scissors (Gentle et al., 1995; Gustafson et al., 2007), cold blade method (Van Liere, 1995), hot blade method (Gentle et al., 1995; Van Liere, 1995), chemical beak-trimming (Van Liere, 1995), electrical debeaking (Gentle et al., 1995), freeze-drying method, as well as robotic and laser beak-trimming (Marchant-Forde et al., 2008). The choice of the method to be used depends on the financial capability of the farmer. Therefore, smallholder farmers inevitably use manual and hot blade methods while large-scale commercial farmers and hatcheries can afford to utilize the electrical, laser, or infrared methods.

The practice of beak-trimming has raised numerous welfare concerns due to its potential to cause acute and chronic pain as well as the loss of function in poultry (Gentle, 2011). Researches have demonstrated that beaktrimming results in acute pain in young poultry, whether performed by the conventional hot-blade method or the new infra-red procedure (Marchant-Forde et al., 2008). Moreover, beak-trimming of adults can lead to the incidence of neuroma and chronic pain (Breward and 
Gentle, 1985; Duncan et al., 1989; Gentle, 1991). The utilization of the conventional hot-blade debeaking method is not usually encouraged since it is an invasive method which can cause stress, pain, and intense suffering in poultry. However, most small-scale farmers still employ this method of beak-trimming with the intention of achieving better productivity (Dennis et al., 2009; Dennis and Cheng, 2010). Furthermore, all manual methods of beak-trimming seem to be inefficient, time-consuming, and are often poorly performed (Dennis et al., 2009). As reported, infra-red trimming can result in a higher decrease of growth and feed intake in the following weeks, compared to the hot-blade trimming method. This means that the pain induced by infra-red beak-trimming may be similar to or more severe than the pain caused by the hotblade method (Honaker and Ruszler, 2004; MarchantForde et al., 2008).

Environmentalists condemn beak-trimming since it is perceived as painful mutilation of the beak which impairs feed and water intake days after trimming (Marchant-Forde et al., 2008) leading to stress and mortality among poultry. Thus, the egg production industry is under intense pressure to stop beak-trimming. However, the abolishment of this procedure in layer farms may negatively impact animal welfare, as it increases the aggressive behaviors of the subjected poultry. (Guesdon et al., 2006; Dennis and Cheng, 2010). Thus, to address welfare concerns and reduce stress and pain following beak-trimming, it is a common practice for veterinarians and farmers to administer anti-stress medications to poultry a day before beak-trimming. However, the efficacy and implications of this practice have not been experimentally supported.

This study was conducted to compare the stress level experienced by eight-week-old pullets following the use of a manual cutter and an electric debeaker for beaktrimming. The study further investigated the effect of prebeak-trimming administration of a vitamin supplement, acetaminophen, and vitamin plus acetaminophen combination on stress-related changes and acute pain responses in pullets.

\section{METHODOLOGY}

\section{Ethical approval}

The protocols used for this research were performed in conformity with the National Institutes of Health revised guidelines for laboratory animals' care and use (NIH, 1985) and approved by the Faculty of Veterinary
Medicine, University of Nigeria, Nsukka (Approval no. UNFVM/11/19/021).

\section{Animals}

One hundred day-old ISA brown pullets were procured from a commercial hatchery and raised in the poultry pen of the Department of Veterinary Medicine, University of Nigeria, Nsukka for eight weeks. The chickens were routinely vaccinated against Newcastle disease, Infectious bursa disease, and fowlpox disease before the start of the study. Water and feed were provided ad libitum throughout the experiment. Before beaktrimming, chickens were dewormed with levamisole $\mathrm{Hcl}$ (100 $\mathrm{g}$ in $200 \mathrm{~L}$ water). The diet contained $15 \%$ crude protein, $8 \%$ fat, 15 crude fibre, $0.9-1.2 \%$ calcium, $0.35 \%$ phosphorus and $2600 \mathrm{Kcal} / \mathrm{Kg}$ of metabolisable energy

\section{Experiment I: Comparison of acute pain induced by beak-trimming using manual beak cutter and electric debeaker \\ Pre-beak-trimming measures}

A total of 20 eight-week-old pullets were assigned to two treatment groups $(n=10)$. Each group of pullets was housed separately. Both groups of chickens were fed predetermined weights (1000 g) of growers ration (Vital feed®, Nigeria) for three days to ascertain their feed intakes. The body weights, heart rates, and rectal temperature of chickens were measured 10 minutes before beak-trimming. Blood $(2 \mathrm{ml})$ was also collected from the jugular vein of each pullet for the determination of packed cell volume (PCV), plasma cortisol level, and total plasma protein level.

\section{Beak-trimming}

One-third of the upper beak of each pullet was trimmed using a manual cutter (group A) and an electric debeaker (group B). Following beak-trimming, chickens were returned to their cages and provided with a weighed quantity (1000 g) of growers ration. Clean medication-free drinking water was also provided for the chickens.

\section{Measured parameters post-beak-trimming}

Feed intake of chickens was determined at 24, 48, 72 , and 96 hours post-beak-trimming. Feed intake by the chicken was determined by weighing the remained feed rations given at $24,48,72$, and 96 hours and subtracting it from the weight of the initial $1000 \mathrm{~g}$ of growers ration fed the previous day. Percentage changes in feed intake per group were subsequently determined. The weight of each chicken was re-determined 24 and 168 hours (day 7) after beak-trimming using a weighing scale. 
At 2, 6, and 24 hours post-beak-trimming, blood was collected from the pullets into EDTA plastic vacutainers for the following laboratory investigations. The PCV was determined using the microhaematocrit methods as described by Natt and Herrick (1952). Plasma was obtained by the centrifugation of anti-coagulated blood to determine cortisol and total plasma protein. Plasma cortisol was measured using a Cortisol ELISA Kit (Medix biotech $\mathrm{kit}^{\circledR}$, USA) according to the manufacturer's instructions. Total plasma protein was determined using the Randox $^{\circledR}$ kit (United Kingdom) under standard conditions.

Heart rate (HR) and temperature were taken 24 hours after beak-trimming. The heart rate was determined with the use of veterinary multi-parameter monitor TM-9009 (Technocare Medisystems, India) and the temperature was determined with a clinical thermometer.

Experiment II: Effect of pre-beak-trimming administration of vitamin supplement, acetaminophen, and vitamin supplement plus acetaminophen on changes in feed intake, body weight, and acute pain response

\section{Pre-beak-trimming protocols}

Forty 8-week-old pullets of similar weights were selected and assigned to four treatment groups. Each group $(\mathrm{n}=10)$ was housed separately and was fed pre-determined weights $(800 \mathrm{~g})$ of growers ration (Vital feed ${ }^{\circledR}$, Nigeria) for three days to ascertain their feed intakes. Medications administered to the groups consisted of vitamin supplement (Vitalyte Extra ${ }^{\circledR}$ United Kingdom; group B), acetaminophen (Sigma Aldrich $^{\circledR}$ Germany; group C), vitamin supplement plus acetaminophen (group D). The vitamin supplement and acetaminophen were included in drinking water of chicken in groups $\mathrm{B}$ and $\mathrm{C}$ at dose rates of 2 and $0.4 \mathrm{~g} / 4$ liters of water, respectively, based on manufacturer recommendations. Drinking water (4 liters) of birds in group D was medicated with $2 \mathrm{~g}$ of a vitamin supplement and 0.4 gram of acetaminophen. The pullets in the treatment groups were allowed access to the medicated water for 1 hour prior to beak trimming. No medication was administered to chickens in group A (control group). Regarding post-beak-trimming, medicated water was provided for chickens in the treatment groups ad libitum for 5 days.

Ten minutes before beak-trimming, blood $(2 \mathrm{ml})$ was collected from the jugular vein of each pullet for the determination of baseline values of PCV, blood glucose, plasma cortisol level, and total plasma protein level.

\section{Beak-trimming}

One-third of the upper beak of each pullet was trimmed using a manual cutter. Following beak-trimming, chickens were returned to their cages and provided with a weighed quantity $(800 \mathrm{~g})$ of growers ration. They were also provided with clean medication-free water.

\section{Parameters measured post-beak-trimming}

Feed intakes were determined 24, 48, 72, and 96 hours after beak-trimming. Feed intake was calculated by subtracting the weight of the remnant feed $24,48,72$, and 96 hours after the initial $800 \mathrm{~g}$ of growers ration fed the previous day. Percentage change in feed intake per group was subsequently determined. At 2, 6, and 24 hours postbeak-trimming, blood was collected from the pullets into EDTA plastic vacutainers for the following laboratory investigations. Blood glucose was determined using a handheld glucometer (Accucheck advantage $\Pi \circledR$ ). PCV, plasma cortisol, and total plasma protein were determined as described in Experiment I. Percentages of changes in the glucose levels of pullets were calculated.

\section{Statistical analysis}

The obtained data were reported as mean \pm standard error of the mean. Mean values of the investigated parameters obtained in Experiment I were compared using the student's T-test while those of Experiment II were compared using one-way ANOVA. Post hoc comparison was performed using LSD at a probability of less than 0.05 .

\section{RESULTS}

\section{Experiment I}

Feed intake

As shown in Figure 1, feed intake of pullets decreased markedly in group A by $98.7 \%$, compared to a $62.97 \%$ decrease in the weight of consumed feed by pullets in group B when compared with the weight of feed consumed before beak-trimming. Furthermore, a decrease in feed intake of group A (19.34\%) was higher than that of group B (17.07\%) 48 hours after beak-trimming. As indicated, 72 hours after beak-trimming, feed intake increased in group B, however, there was a decrease in group A. The findings indicated that 96 hours after beaktrimming, the feed intake of pullets in groups A and B increased by $5.28 \%$ and $22.41 \%$, respectively.

\section{Body weight and vital parameters}

Twenty-four hours after beak-trimming, body weights of chickens in groups $\mathrm{A}$ and $\mathrm{B}$ decreased by $4.09 \%$ and $2.26 \% 24$, respectively. The body weights of 
chickens in groups A and B increased by $11.5 \%$ and $15.98 \%$, respectively, 7 days after beak-trimming (Figure 2 ). Heart rates and rectal temperatures of both groups were not significantly $(\mathrm{p}>0.05)$ different at the investigated post-beak-trimming time points (Table 1).

Packed cell volume, plasma cortisol, total plasma protein

By 2 hours post-beak-trimming, there was a significant decrease of PCV of group A than group B ( $p<$ $0.05)$. There was no significant difference between the PCV of groups at other time points (Table 2). Plasma cortisol of group A was significantly higher than that of group B by 2 and 6 hours post-beak-trimming ( $<0.05$ ). No significant difference was observed among the groups 24 hours after beak-trimming (Table 2). The total protein level of group A was significantly lower than that of group B by 2,6 , and 24 hours post-beak-trimming ( $<<0.05$, Table 2).

\section{Experiment II \\ Feed intake}

The results of the percentage change in feed intake are presented in Figure 3. By 24 hours post-beaktrimming, feed intake in all four groups decreased by 98.97\% (group A), $97.7 \%$ (group B), $93.66 \%$ (group C), and $61.48 \%$ (group D), compared to pre-beak-trimming feed intake. The feed intake decreased 48 hours after beaktrimming in groups $\mathrm{A}, \mathrm{B}, \mathrm{C}$, and $\mathrm{D}$ by $79.7 \%, 92.88 \%$, $42.25 \%$, and $45 \%$, respectively. The results obtained 72 hours post-beak-trimming indicated that feed intake increased in groups $\mathrm{C}$ and $\mathrm{D}$ while there was a decrease in the feed intake in groups A and B were $69.6 \%$ and 10.56\%. Although 72 and 96 hours after beak-trimming the feed intake of chickens increased above the baseline, feed intake in groups $\mathrm{C}$ and $\mathrm{D}$ remained low.

Plasma cortisol, total plasma protein, and blood glucose

The results obtained 2 hours after beak-trimming revealed that plasma cortisol levels of group B, C, and D were significantly lower than that of group A $(p<0.05)$. Cortisol levels of all the groups were not significantly different 6 and 24 hours post-beak-trimming ( $p>0.05$, Table 3). Total plasma protein levels of all the groups were not significantly ( $p>0.05$ ) different 2, 6, 24, and 72 hours post-beak-trimming (Table 3). Glucose levels of chickens in all groups decreased after beak-trimming. Glucose levels in groups A, B, C, and D decreased to $13.85 \%, 15.09 \%, 27.1 \%$, and $20.5 \%$, respectively, 6 hours after beak-trimming. However, 24 hours after beaktrimming, glucose levels of groups A, B, C, and D decreased to $26.83 \%, 25.19 \%, 24.88 \%$, and $5.28 \%$, respectively (Figure 4).

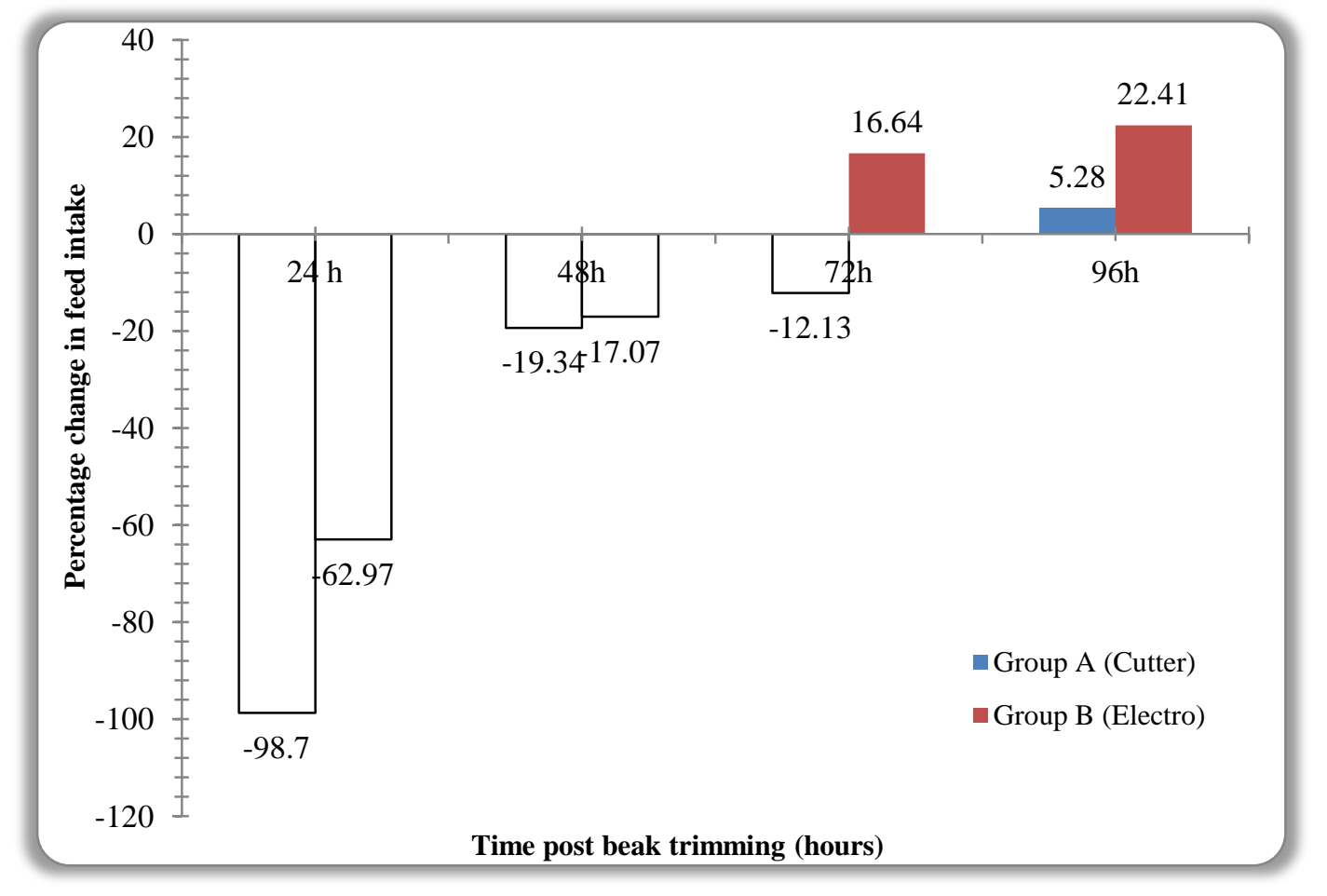

Figure 1. Percentage changes in feed intake of pullets post-beak-trimming using a manual cutter and electro debeaker. 


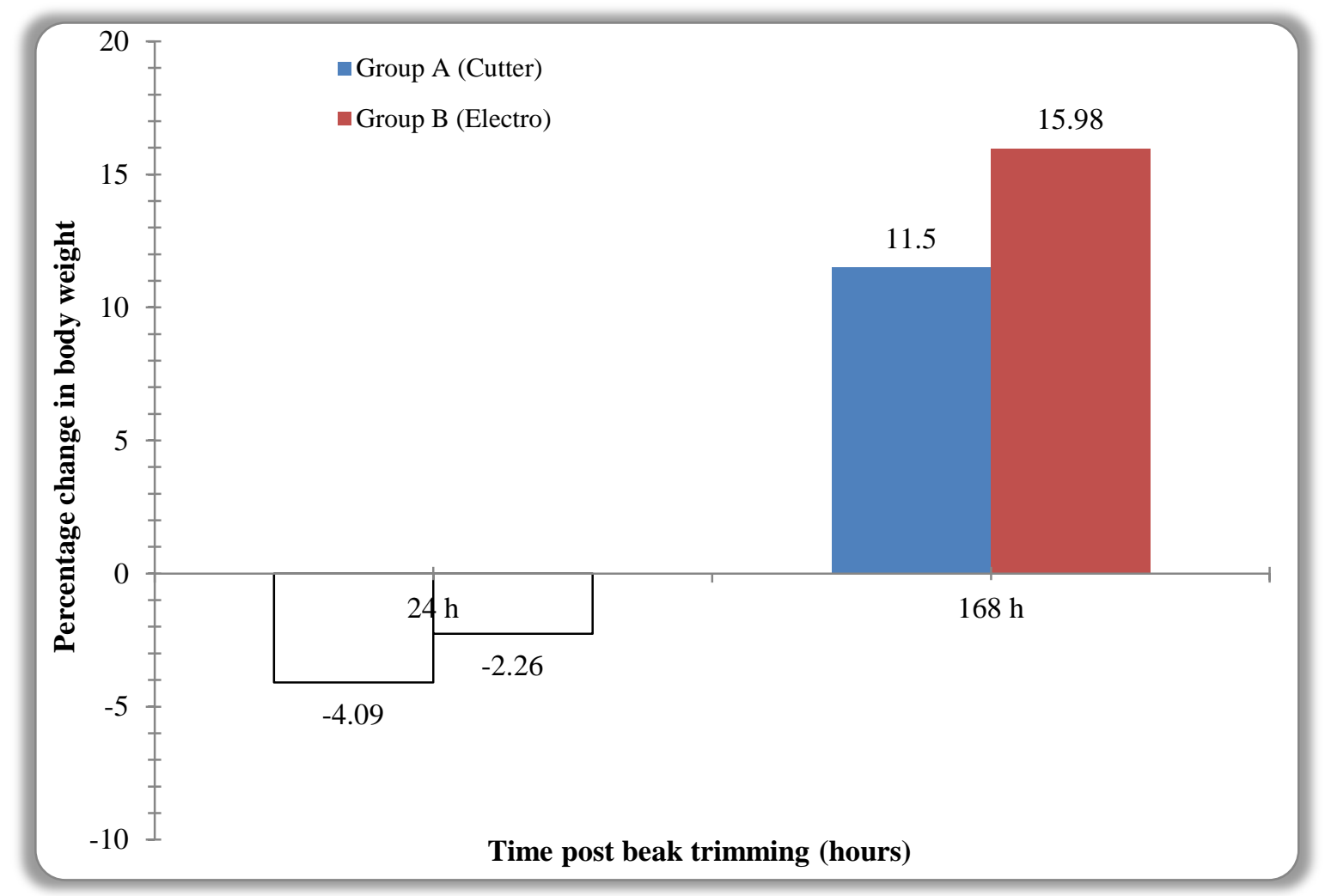

Figure 2. Percentage changes in body weight of pullets post-beak-trimming using the manual cutter and electro debeaker.

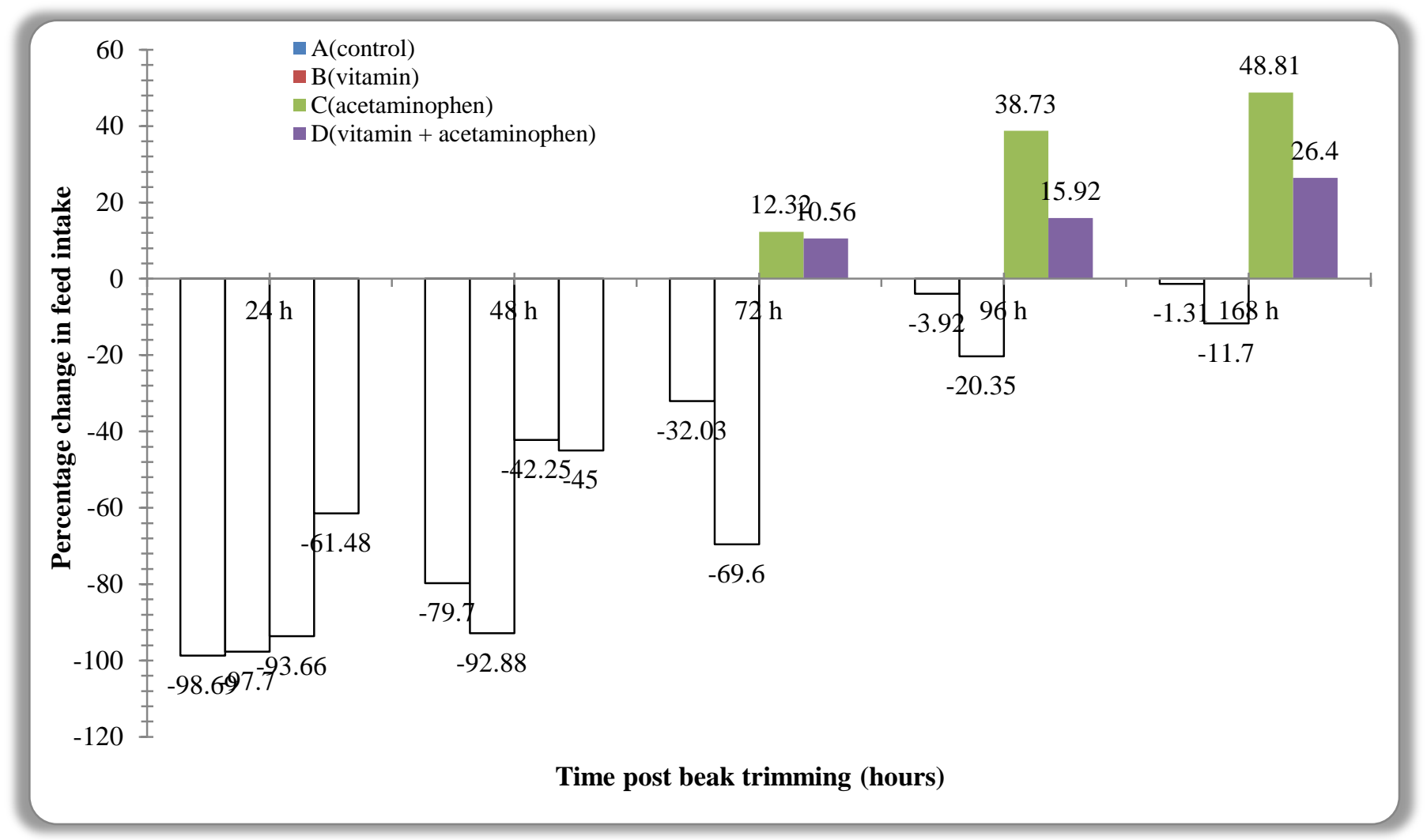

Figure 3. Percentage changes in feed intake of pullets treated with different medications. 


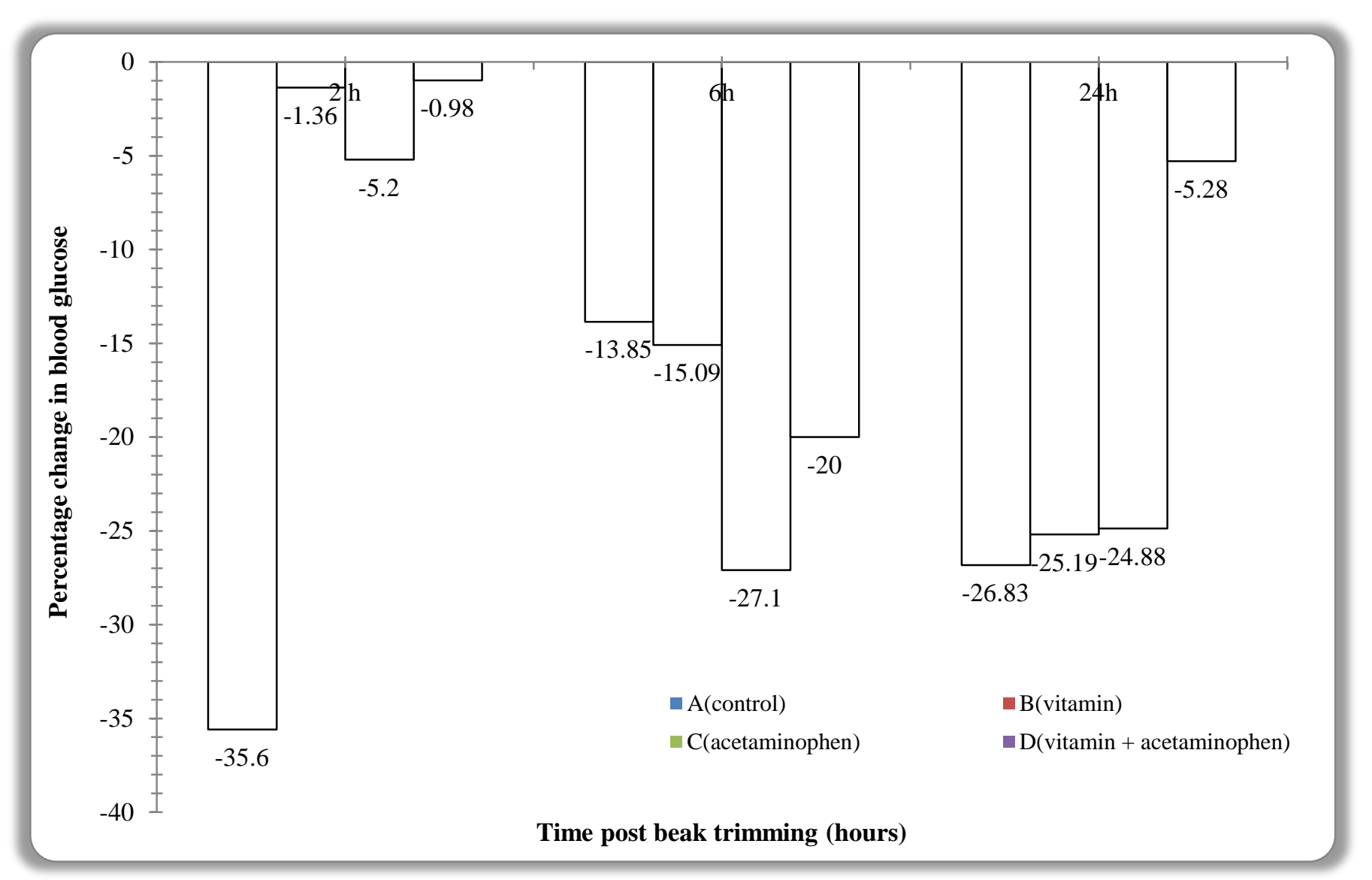

Figure 4. Percentage change in blood glucose of pullets treated with different medications.

Table 1. Heart rate and body temperature of pullets pre and post-beak-trimming using different methods.

\begin{tabular}{lccc}
\hline Parameters & Groups & Pre-beak-trimming & 24 hours PBT \\
\hline Heart rates (beats/min) & Group A & $343.20 \pm 7.73^{\mathrm{a}}$ & $325.60 \pm 8.10^{\mathrm{a}}$ \\
& Group B & $341.60 \pm 11.28^{\mathrm{a}}$ & $356.30 \pm 3.66^{\mathrm{a}}$ \\
\hline \multirow{2}{*}{ Temperature $\left({ }^{\circ} \mathrm{C}\right)$} & Group A & $41.30 \pm 0.14^{\mathrm{a}}$ & $41.06 \pm 0.06^{\mathrm{a}}$ \\
& Group B & $40.96 \pm 6.08^{\mathrm{a}}$ & $41.08 \pm 0.08^{\mathrm{a}}$ \\
\hline
\end{tabular}

*Different superscript letters in a column indicate a significant difference between mean values of groups A and B at p < 0.05 . PBT: Post-beak-trimming. Chickens of group A were beak-trimmed using a manual cutter and group B by electro debeaker.

Table 2. Packed cell volume, cortisol, and total plasma protein levels of pullets pre- and post-beak-trimming using different methods.

\begin{tabular}{|c|c|c|c|c|c|}
\hline Parameters & Groups & Pre-beak-trimming & 2 hours PBT & 6 hours PBT & 24 hours PBT \\
\hline \multirow{2}{*}{ Packed cell volume (\%) } & Group A & $27.2 \pm 0.37^{\mathrm{a}}$ & $20.6 \pm 0.49^{\mathrm{a}}$ & $23.0 \pm 1.05^{\mathrm{a}}$ & $24.0 \pm 5.03^{\mathrm{a}}$ \\
\hline & Group B & $27.6 \pm 0.6^{\mathrm{a}}$ & $23.7 \pm 0.24^{\mathrm{b}}$ & $26.6 \pm 0.34^{\mathrm{a}}$ & $27.2 \pm 0.37^{\mathrm{a}}$ \\
\hline Cortisol ( $\mu \mathrm{g} / \mathrm{dl})$ & Group B & $0.53 \pm 0.07^{\mathrm{a}}$ & $0.66 \pm 0.01^{\mathrm{b}}$ & $0.51 \pm 0.28^{\mathrm{b}}$ & $0.57 \pm 0.13^{\mathrm{a}}$ \\
\hline \multirow{2}{*}{ Total plasma protein $(\mathrm{g} / \mathrm{dl})$} & Group A & $3.58 \pm 0.62^{\mathrm{a}}$ & $3.04 \pm 0.30^{\mathrm{a}}$ & $3.22 \pm 0.16^{\mathrm{a}}$ & $3.50 \pm 0.13^{\mathrm{a}}$ \\
\hline & Group B & $3.32 \pm 0.96^{\mathrm{a}}$ & $3.24 \pm 0.04^{b}$ & $3.00 \pm 0.20^{\mathrm{a}}$ & $4.18 \pm 0.42^{b}$ \\
\hline
\end{tabular}

*Different superscript letters in a column indicate a significant difference between mean values of groups A and B at p < 0.05. PBT: Post-beak-trimming. Chickens of group A were beak-trimmed using a manual cutter and group B by electro debeaker. 
Okoroafor et al., 2021

Table 3. Cortisol and total plasma protein levels of pullets treated with different medications.

\begin{tabular}{lccccc}
\hline Parameters & Groups & Pre-beak-trimming & 2 hours PBT & 6 hours PBT & 24 hours PBT \\
\hline \multirow{3}{*}{ Cortisol $(\mu \mathrm{g} / \mathrm{dl})$} & Group A & $0.67 \pm 0.15$ & $1.51 \pm 0.40^{\mathrm{a}}$ & $0.83 \pm 0.08^{\mathrm{a}}$ & $0.76 \pm 0.09$ \\
& Group B & $0.83 \pm 0.18$ & $0.68 \pm 0.13^{\mathrm{b}}$ & $0.62 \pm 0.08^{\mathrm{b}}$ & $0.62 \pm 0.18$ \\
& Group C & $0.64 \pm 0.16$ & $0.55 \pm 0.97^{\mathrm{b}}$ & $0.71 \pm 0.17^{\mathrm{b}}$ & $0.73 \pm 0.09$ \\
& Group D & $0.68 \pm 0.11$ & $0.46 \pm 0.03^{\mathrm{b}}$ & $0.63 \pm 0.02^{\mathrm{b}}$ & $0.57 \pm 0.09$ \\
\hline \multirow{2}{*}{ Total plasma protein $(\mathrm{g} / \mathrm{dl})$} & Group A & $3.65 \pm 0.26$ & $2.95 \pm 0.14$ & $3.10 \pm 0.06$ & $4.45 \pm 0.49$ \\
& Group B & $3.4 \pm 0.00$ & $3.45 \pm 0.26$ & $3.45 \pm 0.32$ & $3.4 \pm 3.34$ \\
& Group C & $3.45 \pm 0.23$ & $3.03 \pm 0.06$ & $3.35 \pm 0.30$ & $3.85 \pm 0.27$ \\
& Group D & $3.73 \pm 0.06$ & $3.73 \pm 0.42$ & $2.95 \pm 0.14$ & $3.80 \pm 0.36$ \\
\hline
\end{tabular}

*Different superscripts in a column indicate a significant difference between mean values of groups A, B, C, and D at p < 0.05. PBT: Post-beak-trimming. Group A (control), Group B (vitamin supplement), Group C (acetaminophen), and Group D (vitamin supplement plus acetaminophen).

\section{DISCUSSION}

Beak-trimming is acutely painful, as many sensory nociceptors are present in the beak (Van Liere, 1995). Post-beak-trimming behaviors in chickens can be reflected through reduced feed intake, reduced activity, and beak guarding (Gentle et al., 1997; Marchant-Forde et al., 2008). According to Dubbeldam et al. (1995), there was a decrease in the feeding intake time of chickens during the first post-beak-trimming weeks as a result of pain. Thus, the severe decrease in feed intake and body weight of samples in manual beak cutter and electric debeaker groups of the current study could suggest that the samples experienced intense pain at different levels lasting up to 72 hours. This result was not in accordance with previous reports on the outcome of debeaking in very young chickens indicating no clear evidence of prolonged acute pain in chickens. According to these studies, young chickens experienced less pain and no scar tissue or neuroma development after beak-trimming due to rapid regrowth of their beaks (Dubbeldam et al., 1995; Lunam et al., 1996; Gentle et al., 1997). However, in chickens as old as the samples in the current study, studies have shown that the trimmed beak rapidly heals but does not regenerate. The tips of the beaks underlying the epidermis were composed of scar tissues (Breward and Gentle, 1985). In addition, branches of the trigeminal nerve innervating the beak are damaged during beak-trimming while neuromas formed subsequently at the tip of the beak often regress in the early stage of healing (Duncan et al., 1989). However, if severe beak-trimming methods are used, neuromas may persist and exhibit ectopic activity leading to chronic pain in the beak stump (Gentle et al., 1990; Gentle, 1991; Crespo and Shivaprasad, 2003). Therefore, it can be concluded that the short duration of pain in chickens subjected to manual and electric beaktrimming methods in the current study suggests low severity of these two methods. Moreover, a higher decrease in feed intake cum weights of pullets in the group debeaked with manual cutter could suggest that more pain was felt by chickens in this group. Less pain might have been felt in the electro-debeaked pullets since the use of the electric current in debeaking causes complete loss of afferent nerve supply and sensory nerve endings with no neuroma formation (Gentle et al., 1995). Thus, chickens debeaked with the electric debeaker might not experience beak guarding and can resume feeding earlier than their counterparts debeaked with the manual cutter.

The primary glucocorticoid released in response to stress and pain is cortisol (Molony and Kent, 1997). Therefore, serum cortisol assay is recognized as one of the objective methods of assessing stress and pain in many species (Carroll et al., 2006; Keita et al., 2010). Higher plasma cortisol levels among chickens 2 and 6 hours after beak-trimming using the manual cutter suggest that the use of the cutter for chickens could lead to higher levels of stress and pain. This probably leads to higher rates of weight loss and a decrease in the total plasma protein level as also seen in this group.

PCV of pullets in both groups studied decreased following beak-trimming probably because bleeding occurred in the pullets. However, the PCV of the manual cutter group was significantly lower PCV than that of the electro debeaker group in the immediate period ( 2 hours) post-beak-trimming. This suggests that more beak bleeding might have occurred in this group. This finding highlights the advantage of the electro debeaker method of beak-trimming over manual beak-trimming since the beaks are immediately cauterized by the electro debeaker as they are being cut. However, despite this advantage of the electro debeaker, its use is not common in our locality due to their non-availability and cost leaving farmers with no choice but to recourse to the use of manual cutters, such as a simple blade or scissors-like devices. 
Experiment II was conducted to ascertain the efficacy of drugs administered to pullets as anti-stress medications prior to beak-trimming. The outcome of the study showed that administration of acetaminophen and a combination of vitamin plus acetaminophen significantly ameliorated stress and pain in pullets. The use of acetaminophen alone gave the best outcome. This can be seen in the results obtained by 72 hours from the assessment of feed intake and post beak-trimming plasma cortisol assay after 2 and 6 hours. At the aforementioned time points, there was a marked decrease in feed intake and high plasma cortisol levels, compared to results obtained in the control group (that were debeaked using the manual cutter without any form of drug intervention) and the vitamin group. Similarly, Glatz (2000) revealed that analgesics have the potential to ameliorate the initial pain felt by chickens post-beak-trimming, According to Glatz (2000), a mixture of bupivacaine and phenylbutazone can be swabbed unto the beak immediately after beak-trimming. Therefore, the addition of mild analgesics, such as acetaminophen in water for preemptive analgesia prior to manual beak-trimming should be encouraged in layer farms in order to hasten the return to feeding and drinking in chickens.

The current study also showed that blood glucose levels of pullets in all the groups remained decreased significantly for up to 24 hours post-beak-trimming. This was not expected since an increase in blood glucose had characterized the immediate post-trauma period in other animals, such as dogs (Lemke et al., 2002; Ugwu et al., 2020), goats (Udegbunam et al., 2013), and rats (Udegbunam et al., 2012). Blood glucose rise post-trauma had been attributed to post-operative pain which leads to the increased production of epinephrine, norepinephrine, cortisol, growth hormones, and adrenocorticotropic hormone (Kuo et al., 2015). Cortisol also leads to hyperglycemia (Singh, 2003). In addition, catecholamines mainly epinephrine and glucagon activate glycogenolysis and mobilization of glucose principally from muscles with a consequent increase in the production of lactate and glucose (Prunier et al., 2005). There has been no study assessing the glucose response in chicken post-beaktrimming so far. However, it may be assumed that the avian species do not respond to trauma as other species probably due to their small body muscle mass. Regarding glucose response, it is required to include glucose powder in drinking water for pullets during the first few days postbeak-trimming to energize the chickens which exhibit zero to poor feeding due to severe pain induced by beak- trimming. However, this finding excludes the use of glucose rise as an index of severe pain in chicken.

\section{CONCLUSION}

The manual beak cutter and electric debeaker led to intense pain of varying degrees lasting up to 72 hours. This period of acute pain was characterized by a severe decrease in feed intake, weight loss, blood glucose level, $\mathrm{PCV}$, and total plasma protein levels of pullets as well as the increase in serum cortisol level. Accordingly, the administration of acetaminophen and a combination of vitamin plus acetaminophen significantly ameliorated pain in chickens.

\section{DECLARATIONS}

\section{Authors' contribution}

All authors contributed equally to this work.

\section{Acknowledgments}

We acknowledge Mr Ngene and Mr Iyke, the Department of Veterinary Medicine's Laboratory, Faculty of Veterinary Medicine, University of Nigeria, Nsukka for their great help during laboratory analysis of blood samples.

\section{Competing interests}

The authors declare that they have no conflict of interest.

\section{REFERENCES}

Breward J, and Gentle MJ (1985). Neuroma formation and abnormal afferent nerve discharges after partial beak amputation (beak trimming) in poultry. Experientia, 41: 1132-1134. DOI: https://www.doi.org/10.1007/BF01951693

Carroll JA, Berg EL, Strauch TA, Roberts MP, and Kattesh HG (2006). Hormonal profiles, behavioral responses and short term growth performance after castration of pigs at three, six, nine and twelve days of age. Journal of Animal Science, 84: 1271-1278. DOI: https://www.doi.org/10.2527/2006.8451271x

Crespo RE, and Shivaprasad HL (2003). Developmental, metabolic and other noninfectious disorders', In: Saif YM. Diseases of poultry. 11th edn. Ames: Iowa State Press, America, pp. 1055-1056. DOI: https://www.doi.org/10.1002/9781119421481.ch30

Dennis RL, and Cheng HW (2010). A Comparison of Infrared and Hot Blade Beak trimming in Laying Hens. International Journal of Poultry Science, $\quad 9$ : 716-719. https://www.doi.org/10.3923/ijps.2010.716.719

Dennis RL, Fahey AG, and Cheng HW (2009). Infrared beak treatment method compared with conventional hot-blade trimming in laying hens. Poultry Science, 88: 38-43. DOI: https://www.doi.org/10.3382/ps.2008-00227 
Dubbeldam JL, De Bakker MAG, and Bout RG (1995). The composition of trigeminal nerve branches in normal adult chickens and after debeaking at different ages. Journal of Anatomy, 186: 619-627. Available https://www.ncbi.nlm.nih.gov/pmc/articles/PMC1167019/

Duncan IJH, Slee GS, Seawright E, and Breward J (1989). Behavioural consequences of partial beak amputation (beak-trimming) in poultry. British Poultry Science, 30: 479-488. DOI: https://www.doi.org/10.1080/00071668908417172

Fournier J, Schwean-Lardner K, Knezacek TD, Gomis S, and Classen HL (2015). The effect of toe trimming on behavior, mobility, toe length and other indicators of welfare in tom turkeys. Poultry Science, 94: 1446-1453. DOI: https://www.doi.org/10.3382/ps/pev112

Gentle MJ (1991). The acute effects of amputation on peripheral trigeminal afferents in Gallus gallusvardomesticus. Pain, 46: 97103. DOI: https://www.doi.org/10.1016/0304-3959(91)90039-z

Gentle MJ (2011). Pain issues in poultry. Applied Animal Behaviour Science, 135: 252- 258. Available at: https://www.internationalegg.com/wpcontent/uploads/2015/11/Gentle\%20-\%202011.pdf

Gentle MJ, Hughes BO, Fox A, and Waddington D (1997). Behavioural and anatomical consequences of two beak trimming methods in 1and 10-day-old chicks. British Poultry Science, 38: 453-463. DOI: https://www.doi.org/10.1080/00071669708418022

Gentle MJ, Thorp BH, and Hughes BO (1995). Anatomical consequences of partial beak amputation (beak trimming) in turkeys. Research in

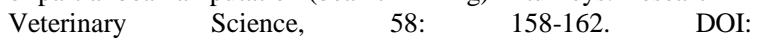
https://www.doi.org/10.1016/0034-5288(95)90070-5

Gentle MJ, Waddington D, Hunter LN, and Jones RB (1990). Behavioural evidence for persistent pain following partial beak amputation in chickens. Applied Animal Behaviour Science, 27: 149-157. Available at: https://www.doi.org/10.1016/01681591(90)90014-5

Glatz PC (2000). Beak-trimming methods -Review. Asian Australasian Journal of Animal Sciences, 13(11): 1619-1637. DOI: https://www.doi.org/10.5713/ajas.2000.1619

Guesdon V, Ahmed S, Mallet S, Faure JM, and Nys Y (2006). Effects of beak trimming and cage design on laying hen performance and egg quality. British Poultry Science, 47(1): 1-12. DOI: https://www.doi.org/10.1080/00071660500468124

Gustafson LA, Cheng HW, Garner JP, Pajor EA, and Mench JA (2007). Effects of bill-trimming Muscovy ducks on behavior, body weight gain, and bill morphopathology. Applied Animal Behaviour

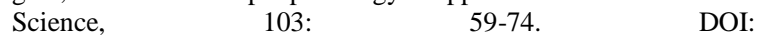
https://www.doi.org/10.1016/j.applanim.2006.04.003

Honaker CF, and Ruszler PL (2004). The effect of claw and beak reduction on growth parameters and fearfulness of two leghorn strains. Poultry Science, 83: 873-881. DOI: https://www.doi.org/10.1093/ps/83.6.873

Keita A, Pagot E, Prunier A, and Guidarini C (2010). Preemptive meloxicam for post-operative analgesia in piglets undergoing surgical castration. Veterinary Anesthetics and Analgesics, 37: 367-374. DOI: $\quad$ https://www.doi.org/10.1111/j.14672995.2010.00546.x

Kuo T, Allison M, Chen TC, and Wang JC (2015). Regulation of Glucose Metabolism by Glucocorticoids. Advance in
Experimental Medicine and Biology, 872: 99-126. DOI: https://www.doi.org/10.1007/978-1-4939-2895-8 5

Lemke KA, Runyon CL, and Honey BS (2002). Effect of preoperative administration of ketoprofen on anaesthetic requirements and signs of postoperative pain in dogs undergoing elective ovariohysterectomy. Journal of American Veterinary Medical

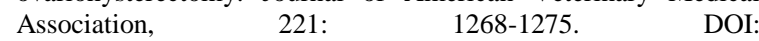
https://www.doi.org/10.2460/javma.2002.221.1268

Lunam CA, Glatz PC, and Hsu YJ (1996). The absence of neuromas in beaks of adult hens after conservative trimming at hatch. Australia

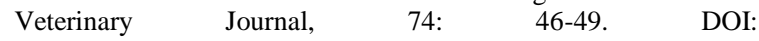
https://www.doi.org/10.1111/j.1751-0813.1996.tb13734.x

Marchant-Forde RM, Fahey AG, and Cheng HW (2008). Comparative effects of infrared and one-third hot-blade trimming on beak topography, behaviour, and growth. Poultry Science, 87: 14741483. DOI: https://www.doi.org/10.3382/ps.2006-00360

Molony V, and Kent J (1997). Assessment of acute pain in farm animals using behavioural and physiological measurements. Journal of Animal Science, 75: 226-272. DOI: https://www.doi.org/10.2527/1997.751266x

National Institute of Health (NIH) (1985). Guide for the Care and Use of Laboratory Animal (Revised). $8^{\text {th }}$ Edition. National Academies Press, 500 Fifth Street, NW, Lockbox 285, Washington, DC, United States of America, Pp. 83-123. Available at: https://grants.nih.gov/grants/olaw/guide-for-the-care-and-use-oflaboratory-animals.pdf

Natt MP, and Herrick CA (1952). A new blood diluent for counting the erythrocytes and leucocytes of the chicken. Poultry Science, 31: 735-738. DOI: https://doi.org/10.3382/ps.0310735

Prunier A, Mounier A, and Hay M (2005). Effects of castration, tooth resection or tail docking on plasma metabolites and stress hormones in young pigs. Journal of Animal science, 83: 216-222. DOI: https://www.doi.org/10.2527/2005.831216x

Singh M (2003). Stress response and anaesthesia: Altering the peri and post operative management. Indian Journal of Anaesthesia, 47: 427-434. Available https://www.ijaweb.org/temp/IndianJAnaesth476427$\underline{6613992 \text { 182219.pdf }}$

Udegbunam RI, Agu NN, and Udegbunam So (2012). Efficacy of piroxicam on acute pain induced by full thickness excision wounds in rats. African Journal of Pharmacy and Pharmacology, 6(23): 1668-1674. DOI: http://www.doi.org/10.5897/AJPP12.113

Udegbunam RI, Asuzu IU, Kene ROC, and Udegbunam SO (2013). Local anaesthetic and tissue effects of the leaf extract and fractions of Sterculia tragacantha. Journal of Pharmacology and $\begin{array}{llll}\text { Toxicology, } & 7(4) \text { : } & 192-198 . & \text { DOI: }\end{array}$ http://www.doi.org/10.3923/jpt.2012.192.198

Ugwu NE, Eze CA, Udegbunam RI, and Nnaji TO (2020). Perioperative analgesic efficacy of constant rate infused tramadol hydrohloride as an adjunct to postoperative ketoprofen in ovariohysterectomized bitches. Indian Journal of Animal Research, 54(5): 627-630. http://www.doi.org/10.18805/ija.B-984

Van Liere DW (1995). Responsiveness to a novel preening stimulus long after partial beak amputation (beak trimming) in laying hens. Behaviour Processes, 34: 169-174. DOI: https://www.doi.org/10.1016/0376-6357(94)00066-p 